\title{
VIABILITY OF STAPHYLOCOCCUS XYLOSUS ISOLATED FROM ARTISANAL SAUSAGES FOR APPLICATION AS STARTER CULTURES IN MEAT PRODUCTS
}

\author{
Ângela Maria Fiorentini ${ }^{1,2 *}$; Maristela Cortez Sawitzki ${ }^{1}$; Teresinha Marisa Bertol ${ }^{3}$; \\ Ernani S. Sant'Anna ${ }^{1}$
}

\begin{abstract}
${ }^{1}$ Departamento de Ciência e Tecnologia de Alimentos, Centro de Ciências Agrárias, Universidade Federal de Santa Catarina, Florianópolis, SC, Brasil; ${ }^{2}$ Universidade Regional, Departamento de Biologia e Química, Santa Rosa, RS, Brasil; ${ }^{3}$ EMBRAPA SUÍNOS e AVES, Concórdia, SC, Brasil
\end{abstract}

Submitted: August 22, 2007; Returned to authors for corrections: October 10, 2007; Approved: November 05, 2008.

\begin{abstract}
Viability of Staphylococcus xylosus isolated from artisanal sausages for application as starter cultures in meat products Viability of Staphylococcus xylosus strains AD1 and U5 isolated from natural fermented sausages was investigated as starter cultures in fermented sausages produced in the South Region of Brazil. The study demonstrated that the Staphylococcus xylosus strains AD1 and U5 showed significant growth during fermentation, stability over freeze-dried process, negative reaction for staphylococcal enterotoxins and viability for using as a single-strain culture or associated with lactic acid bacteria for production of fermented sausages.
\end{abstract}

Key words: Staphylococcus xylosus, starter cultures, sausages

\section{INTRODUCTION}

Different microorganisms from raw materials and environment are natural contaminants of dry sausage mixtures (15). Micrococcaceae, as well as Lactic Acid Bacteria (LAB) are important microorganisms used as starter cultures in meat fermentation in order to improve safety and stability of the product, extend shelf life and provide diversity, resulting in new sensory properties (17).

Staphylococcus xylosus (Micrococcaceae) is one of the most commonly staphylococci species found in many Italian and Spanish sausages $(2,6,13)$, in Slovak meat products $(26)$ and in Tunisian traditional salted meat (10). This species is used in meat industry as starter culture in fermented sausages due to its technological properties, once it ensures color development by nitrite and nitrate reductase and catalase activities, contributing to flavor development as a result of proteolytic and lipolytic activities (18). Selection of autochthonous microflora may be used in order to preserve typical characteristics of these products (19). Besides, the most promising starter strains are those isolated from naturally fermented meat products once they are the dominant and the well adapted population (8).

However, to select a suitable strain for using as a starter culture, technological properties and safety aspects must be considered. So, the ability of coagulase-negative staphylococci (CNS) to produce antagonistic substances against pathogenic bacteria $(23,26)$ may be important for the safety of sausages. On the other hand, some strains of S. xylosus, S. saprophyticus and Staphylococcus. spp from food can produce enterotoxins $(22,25)$. Staphylococcal enterotoxins (SE) belong to a family of nine major serological types of heat stable enterotoxins that cause gastroenteritis (14). According to McLauchlin et al. (20), the presence of toxin genes confirmed by PCR (Polymerase Chain Reaction) does not necessarily imply the capacity of a microorganism in producing biologically active toxins enough to induce clinical manifestations. Nevertheless, it should be demonstrated that enterotoxins are not produced in CNS strains selected to use as starter cultures (23).

Micrococcaceae strain might not present antagonistic activity against LAB to be selected as starter culture, but a

*Corresponding Author. Mailing address: Departamento de Ciência e Tecnologia de Alimentos, Centro de Ciências Agrárias, Universidade Federal de Santa Catarina, Rod. Admar Gonzaga, 1346, 880034-001, Florianópolis, SC, Brasil. E-mail: afiore@unijui.edu.br 
synergism between these two groups is essential. This group contributes mainly to lactic acid production, which inhibits growth of pathogens (17). Starter cultures consisting of a mix of lactic acid bacteria and Micrococcaceae have been used in industrial manufacture of dry fermented sausages (4).

In order to preserve these isolated bacteria for long periods, methods to keep the viability of cultures are necessary. Lyophilization (freeze-drying) is considered one of the best processes to preserve the viability of microorganisms and particularly of bacteria and moulds (11). The most important advantages of freeze-dried starter preparations are the excellent storage stability and the easy handling during storage, distribution and application (4).

The aim of the present work was to investigate the viability of Staphylococcus xylosus strains AD1 and U5, isolated from naturally fermented sausages, for further use as starter cultures in meat products, as well as safety aspects.

\section{MATERIALAND METHODS}

\section{Bacterial strains}

Staphylococcus xylosus was the dominant species (42.8\%) among strains isolated from naturally fermented sausages in the South Region of Brazil by phenotypical characterization. Two strains (AD1 and U5) were confirmed as $S$. xylosus species in molecular characterization. Both strains were selected for this study regarding to its properties: catalase positive activity, capacity to reduce nitrate and nitrite and lipolytic activity.

Reference strains used in tests were from the Collection André Tosello Foundation (Brazil): Lactobacillus plantarum ATCC 8014, Listeria monocytogenes NTC 098630, Escherichia coli ATCC 25922 and Staphylococcus aureus ATCC 12598. One strain of Lactobacillus plantarum isolated from naturally fermented sausage produced in the South region (Brazil) was also used in the tests.

\section{Cultivation of strains}

Cultivations were initiated from stock cultures plated on $\mathrm{BHI}$ agar (Brain Heart Infusion, MERCK) and incubated $\left(35^{\circ} \mathrm{C} /\right.$ 18h). A single colony was incubated in BHI broth (MERCK) $\left(35^{\circ} \mathrm{C} / 18 \mathrm{~h}\right)$ and $1 \%$ inoculum of the cell suspension was transferred to BHI broth (MERCK). Finally, $1 \%$ inoculum was transferred to a fermenter (New Brusnswick Scientific, model Bioflo 2000, USA) with 4.5 L of BHI broth (MERCK). Fermentation was carried out under the following conditions: $35^{\circ} \mathrm{C} \pm 0.1^{\circ} \mathrm{C}$, with stirring of $100 \mathrm{rpm}$ and aeration of $0.7 \mathrm{vvm}(\mathrm{L}$ of air/L half/minute) for $24 \mathrm{~h}$.

Samples, in triplicate, were aseptically collected in sterile flasks every 2 hours during the fermentation period. Counting of viable cells was carried out by cultivation in plates, in BHI agar (MERCK) and incubated $\left(35^{\circ} \mathrm{C} / 48 \mathrm{~h}\right)$. Optical density (OD) readings of the fermentation medium were performed in spectrophotometer (Hitachi U 2010) at $630 \mathrm{~nm}$, according to Kanasaki et al. (14).

\section{Fermentation and freeze-drying}

Staphylococcus xylosus cells (AD1 and U5) (initial inoculum of $10^{9}$ cfu. $\mathrm{mL}^{-1}$ ) were grown in a fermenter (New Brusnswick Scientific, model Bioflo 2000, USA), as described above, for 10 to $12 \mathrm{~h}$.

Cells were concentrated by centrifugation at $4000 \mathrm{x} g$, for 30 $\min$ at $4^{\circ} \mathrm{C}$ (Novatécnica RC, model NT825, Brazil), resuspended to $1 / 50$ of the original broth volume in reconstituted skimmed milk $(10 \% \mathrm{w} / \mathrm{w})$ as cryoprotectant and frozen at $-20^{\circ} \mathrm{C}$. Freezedrying was performed in a freeze-dryer (Terroni Fauvel mod. LT $1000 / 8$, Brazil) for 18 to $24 \mathrm{~h}$. Freeze-dried cultures were stored at $-20^{\circ} \mathrm{C}$, until use. For each strain, fermentation and freezedrying experiments, as well as stability studies, were performed in duplicate.

\section{Storage stability}

Freeze-dried cultures were stored at $-20^{\circ} \mathrm{C}$ for two different periods: up to 1 month or 6 months. After the storage periods, freeze-dried cultures were resuspended in sterile $0.1 \%$ peptone water (MERCK) $(10 \mathrm{mg} / 100 \mathrm{~mL}$ and subsequent dilutions) and grown on BHI agar (MERCK) plates $\left(35^{\circ} \mathrm{C} / 48 \mathrm{~h}\right)$. Bacterial population was determined by plate count analysis in order to evaluate the stability of the cultures at $-20^{\circ} \mathrm{C}$.

\section{Enterotoxin detection}

For enterotoxin measurement, a VIDAS autoanalyzer (Biomerieux, Brazil) and a VIDAS ${ }^{\circledR}$ Staph enterotoxin SET kit (Biomerieux, Brazil) were used. The principle of this measurement system is an enzyme-linked fluorescent assay (ELFA) using polyclonal anti-enterotoxin antibody and seven enterotoxin serotypes (SEA, SEB, SEC1, 2, 3, SED and SEE) (3). Results were expressed as relative fluorescence value (RFV). The RFV obtained is analyzed by the VIDAS system as follows: when Test Value $(\mathrm{TV})<0.13$, negative result and $\mathrm{TV} \geq 0.13$, positive result.

\section{Antagonistic activity}

Antagonistic effects of isolated Staphylococcus xylosus (AD1, U5) were detected by 'spot on the lawn' method $(16,21)$. Plates with tryptic soy agar supplemented with $0.6 \%$ yeast extract (TSAYE, MERCK) as bottom agar, were spotted with $2 \mu \mathrm{L}$ of each overnight BHI broth (MERCK) cultures containing $S$. xylosus strains (AD1, U5) and incubated anaerobically at $35^{\circ} \mathrm{C}$ for $48 \mathrm{~h}$. After incubation, an overlay of about $8 \mathrm{~mL}$ of BHI broth (MERCK) containing 1\% agar was added in each plate, which were respectively seeded $\left(10^{5}-10^{6} \mathrm{cfu} \mathrm{mL}^{-1}\right)$ with $L$. plantarum ATCC 8014, L. plantarum isolated from artisanal sausage, $L$. monocytogenes NTC 098630, E. coli ATCC 25922, and S. aureus ATCC 12598. Plates with the overlay and one control plate (no 
addition of the indicative culture) were incubated anaerobically at $30^{\circ} \mathrm{C}$ for $48 \mathrm{~h}$. A halo of inhibition around the microorganism growth indicated the antagonistic activity.

\section{RESULTS AND DISCUSSION}

Strains confirmed as Staphylococcus xylosus by molecular characterization (AD1, U5) were selected for further studies. They were cultivated in BHI broth (MERCK), being monitored by cell counting and by OD readings, during $24 \mathrm{~h}$. Fig. 1 (a) and (b) shows that, after $10 \mathrm{~h}$ of fermentation with strains AD1 and U5, the relative absorbances of 1.346 and 1.702, respectively, were observed when the cell counting was of $10^{11} \mathrm{cfu} \mathrm{mL}^{-1}$. The $\mathrm{pH}$ of the fermentation medium presented a small reduction in the initial period $(2-6 \mathrm{~h})$ remaining constant until the end of the fermentation (Fig. 1 (c)).

Fermentation was monitored by OD readings and interrupted at $10 \mathrm{~h}$ (logarithmic growth phase), when the values obtained by spectrophotometric readings at $630 \mathrm{~nm}$ reached the relative cell counting of $10^{11} \mathrm{cfu} \mathrm{mL}-10^{-1} \mathrm{cfu} \mathrm{mL} \mathrm{m}^{-1}$.

The amount of inoculum to be used for sausage manufacturing depends on the potential of microorganisms to grow in the product, being necessary around $10^{6}-10^{8} \mathrm{cfu} \cdot \mathrm{g}^{-1}$ of product (17). Therefore, when using AD1 and U5 strains as starter cultures in sausages, it was necessary a period of about $10 \mathrm{~h}$ of fermentation in order to obtain the desired number of cells $\left(10^{11}\right.$ cfu.mL $\left.\mathrm{mL}^{-1}\right)$.

Desirable storage conditions for freeze-dried starters are: freezing temperatures below $-15^{\circ} \mathrm{C}$ and absence of oxygen and humidity. Under these conditions, the optimal activity of the starter culture will be guaranteed for 8 months (4). In this study, cultures of S. xylosus strains AD1 and U5 stored for 1 month and 6 months at $-20^{\circ} \mathrm{C}$ presented good stability by freeze-drying process (Table 1). A small decrease in the number of cells was observed during storage, remaining at $10^{11} \mathrm{cfu} \mathrm{mL}{ }^{-1}$. This stability is probably due to the positive effect of storage conditions and also the cryoprotectant used (skimmed milk). According to Carvalho et al. (5), skimmed milk is able to prevent cellular injury
Table 1. Countings of the $S$. xylosus AD1 and U5 strains after the freeze-dried (initial) and during the period of storage at $-20^{\circ} \mathrm{C}$.

\begin{tabular}{lccc}
\hline & $\begin{array}{c}\text { Initial } \\
\left(\mathrm{cfu} . \mathrm{mL}^{-1}\right)\end{array}$ & $\begin{array}{c}1 \text { month } \\
\left(\mathrm{cfu} . \mathrm{mL}^{-1}\right)\end{array}$ & $\begin{array}{c}6 \text { month } \\
\left(\mathrm{cfu} . \mathrm{mL}^{-1}\right)\end{array}$ \\
\hline S. xylosus AD1 & $2.9 \times 10^{11}$ & $2.5 \times 10^{11}$ & $1.0 \times 10^{11}$ \\
S. xylosus U5 & $4.1 \times 10^{11}$ & $3.9 \times 10^{11}$ & $3.4 \times 10^{11}$ \\
\hline
\end{tabular}

by stabilizing the cell membrane and providing a protective coating for the cells.

Staphylococcal enterotoxins were not found in S. xylosus strains AD1 and U5 once it showed negative result for this analysis. This is an important characteristic of the species used in starter cultures because several studies have demonstrated the capacity of negative coagulase staphylococci (CNS) in producing enterotoxins $(7,27)$, a feature related to positive coagulase species. However, few studies have been performed in order to determine enterotoxigenic capacity of CNS in foods. Ninety samples of industrialized salamis were analyzed by Pereira (24), where none out of $266 \mathrm{CNS}$ strains produced enterotoxins and 252 out of 266 were identified. About $90 \%$ were S. xylosus and $S$. carnosus.

The isolated strains of $S$. xylosus (AD1 and U5) did not exhibit antimicrobial activity against the following pathogenic strains in the tested conditions: L. monocytogenes NTC 098630, E. coli ATCC 25922, and S. aureus ATCC 12598, once an inhibitory halo around the analyzed colony (Table 2) was not observed. Similar results were reported by Drosinos et al. (9), where no Staphylococcus spp. presented antimicrobial activity against L. monocytogenes NCTC 10527, S. aureus NCBF 1499, and E. coli O157:H7 NCTC 12079. Tested strains (AD1 and U5) did not present inhibitory activity against $L$. plantarum ATCC 8014 and an isolated strain of L. plantarum.

The majority of $S$. xylosus strains presented technological properties allowing their use as starter cultures for fermented

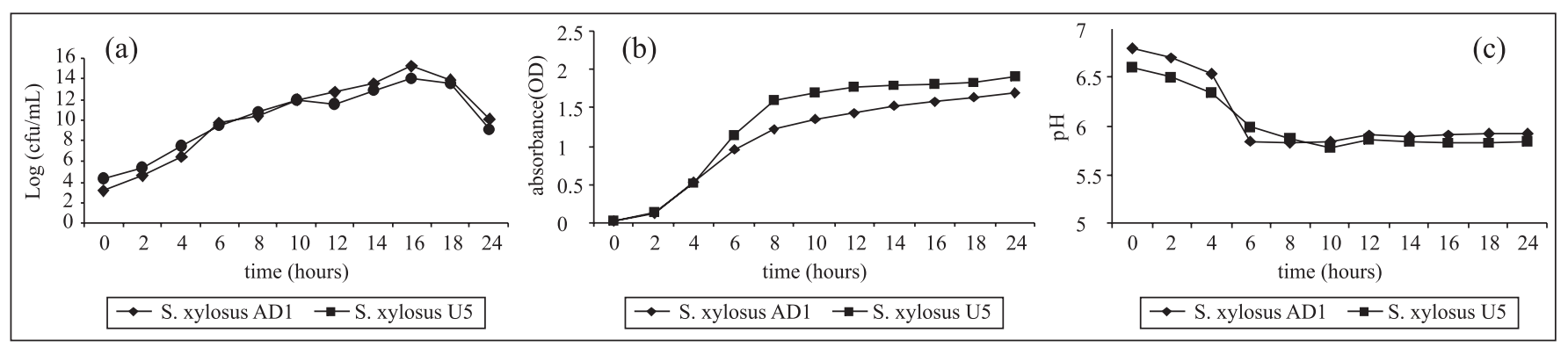

Figure 1. Fermentation of Staphylococcus xylosus AD1 and U5 in BHI broth at $35^{\circ} \mathrm{C}$. a) Counting of viable cells at the time of fermentation; b) Curve of absorbance relative at the time of fermentation; c) Variation of the $\mathrm{pH}$ of the medium of fermentation. 
Table 2. Antimicrobial activity of the S. xylosus strains isolated against selected strains.

\begin{tabular}{lcc}
\hline & S. xylosus & S. xylosus \\
& AD1 & U5 \\
\hline L. plantarum ATCC 8014 & - & - \\
L. plantarum strain Isolated & - & - \\
S. aureus ATCC 12598 & - & - \\
E. coli ATCC 25922 & - & - \\
L. monocytogenes NTC 098630 & - & - \\
\hline
\end{tabular}

Symbols for well diffusion assay: + , large inhibition zone (width $\geq 3.0$ $\mathrm{mm}$ ); $(+)$, small inhibition zone (width $\leq 3.0 \mathrm{~mm}$ ); -, no inhibition zone.

meat products $(12,19)$. In particular, strains AD1 and U5 were able to grow during fermentation in BHI broth, showed stability in the freeze-dried process and presented good activity in the studied properties such as absence of antagonistic activity against lactic acid bacteria and negative reaction of staphylococcal enterotoxins.

The study demonstrated the viability of Staphylococcus xylosus $\mathrm{AD} 1$ and $\mathrm{U} 5$ strains for using as a single-strain culture or associated with lactic acid bacteria (LAB) for the production of fermented sausages.

\section{ACKNOWLEDGEMENTS}

This research was supported by EMBRAPA, UNIJUÍ and UFSC, Brazil.

\section{RESUMO}

\section{Viabilidade de Staphylococcus xylosus isoladas de embutidos artesanais para aplicação como cultivos iniciadores em produtos cárneos}

Investigamos a viabilidade de cepas de Staphylococcus xylosus (AD1 e U5) isoladas de embutidos com fermentação natural, para aplicação como cultivos iniciadores em embutidos fermentados produzidos na Região Sul do Brasil. O estudo demonstrou que cepas de Staphylococcus xylosus (AD1 e U5) apresentaram crescimento significativo durante a fermentação, estabilidade no processo de liofilização e conservação, ausência de produção de enterotoxinas e viabilidade para aplicação como cultivo iniciador simples ou associado com bactérias lácticas na elaboração de embutidos fermentados.

Palavras chave: Staphylococcus xylosus, cultivos iniciadores, embutidos cárneos

\section{REFERENCES}

1. Balaban, N.; Rasooly, A. (2000). Staphylococcal enterotoxins. Int. J. Food Microbiol., 61, 1-10.

2. Blaiotta, G.; Pennacchia, C.; Villani, F.; Ricciardi, A.; Tofalo, R.; Parente, E. (2004). Diversity and dynamics of communities of coagulasenegative staphylococci in traditional fermented sausages. J. Appl. Microbiol. 97, 271-284.

3. Bergdoll, M.S. (1983). Enterotoxins I: Staphylococci and Staphylococcal infections. In: Easmon, C.; Adiam, C. (eds). Academic Press, New York, USA, 2, 559-598.

4. Buckenhüskes, H.J. (1993). Selection criteria for lactic acid bacteria to be used as starter cultures for various food commodities. FEMS Microbiol. Rev., 12, 253-272.

5. Carvalho, A.S.; Silva, J.; Ho, P.; Teixeira, P.; Malcata, F.X.; Gibbs, P. (2004). Relevant factors for the preparation of freeze-dried lactic acid bacteria. Int. Dairy J., 14, 835-847.

6. Cocolin, L.; Manzano, M.; Aggio, D.; Cantoni, C.; Comi, G. (2001). A novel polymerase chain reaction (PCR)-denaturing gradient gel electrophoresis (DGGE) for the identification of Micrococcaceae strains involved in meat fermentations. Its application to naturally fermented Italian sausages. Meat Sci., 57, 59-64.

7. Crass, B.A.; Bergdoll, M.S. (1986). Involvement of coagulasenegative staphylococci in toxic shock syndrome. J. Clin. Microbiol., $23,43-45$.

8. Drosinos, E.H.; Mataragas, M.; Xiraphi, N.; Moschonas, G.; Gaitis, F.; Metaxopoulos, J. (2005). Characterization of the microbial flora from a traditional Greek fermented sausage. Meat Sci., 69, 307-317.

9. Drosinos, E.H.; Paramithiotis, S.; Kolovos, G.; Tsikouras, I.; Metaxopoulos, I. (2007). Phenotypic and technological diversity of lactic acid bacteria and staphylococci isolated from traditionally fermented sausages in Southern Greece. Food Microbiol. 24, 260270 .

10. Essid, I.; Ismail, H.B.; Ahmed, S.B.H.; Ghedamsi, R.; Hassouna, M. (2007). Characterization and technological properties of Staphylococcus xylosus strains isolated from a Tunisian traditional salted meat. Meat Sci., 77, 204-212.

11. Figueiredo, M.B. (2001). Métodos de preservação de fungos patogênicos. Biológico. v.63, n.1/2, p.73-82, jan/dez.

12. Fiorentini, A.M.; Sawitzki, M.C.; Bertol, T.M.; Brod, F.C.A.; Pelisser, M.R.; Arisi, A.C.M.; Sant'Anna, E.S. (2007). Phenotypic and molecular characterization of Staphylococcus xylosus: Technological potencial for use in fermented sausage. Braz. Arch. of Biol. and Technol. Accepted for publication.

13. Garcia-Varona, M.; Santos, E.M.; Jaime, I.; Rovira, J. (2000). Characterisation of Micrococcaceae isolated from different varieties of chorizo. Int. J. Food Microbiol. 54, 189-195.

14. Kanasaki, M.; Breheny, S.; Hillier, A.J. et al. (1975). Effects of temperature on growth and acid production of lactic acid bacteria. $J$. Food Prot., 142-144.

15. Larrouture, C.; Ardaillon, V.; Pépin, M.M.; Montel, M.C. (2000). Ability of meat starter cultures to catabolize leucine and evaluation of the degradation products by using an HPLC method. Food Microbiol., 17, 563-570.

16. Lewus, C.B.; Kaiser, A.; Montville, T.J. (1991). Inhibition of foodborne bacterial pathogens by bacteriocins from lactic acid bacteria isolated from meat. Appl. Environ. Microbiol., 57(6), 1683-1688.

17. Lücke, F.K. (2000). Utilization of microbes to process and preserve meat. Meat Sci., 56, 105-115.

18. Martín, B.; Garriga, M.; Hugas, M.; Bover-Cid, S.; Veciana-Nogués, M.T.; Aymerich, T. (2005). Molecular, technological and safety characterization of Gram-positive catalase-positive cocci from slightly fermented sausages. Food Microbiol., 107(2), 148-58. 
19. Mauriello, G.; Casaburi, A.; Blaiotta, G.; Villani, F. (2004). Isolation and technological properties of coagulase negative staphylococci from fermented sausages of Southern Italy. Meat Sci., 67, 149-158.

20. Mclauchlin, J.; Narayanan, G.L.; Mithani, V. et al. (2000). The detection of enterotoxins and toxic shock syndrome toxin genes is Staphylococcus aureus by polymerase chain reaction. J. Food Prot., v. $63,479-488$.

21. Okereke, A.; Montville, T.J. (1991). Bacteriocin inhibition of Clostridium botulinum spores by lactic acid bacteria. J. Food Prot., 54(5), 349-353.

22. Padmapriya, B.P.; Ramesh, A.; Chandrashekar, A.; Varadaj, M.C. (2003). Staphylococcal accessory gene regulator sar as a signature gene to detect enterotoxigenic staphylococci. J. Appl. Microbiol., 95, 974-981.

23. Papamanoli, E.; Kotzekidou, P.; Tzanetakis, N.; LitopoulouTzanetaki, E. (2002). Characterisation of Micrococcaceae isolated from dry fermented sausage. Food Microbiol. 19, 441-449.
24. Pereira, K.S.; Pereira, J.L. (2006). Identificação e verificação do potencial enterotoxigênico de Staphylococus ssp. coagulase negativa isolados a partir de salames brasileiros industrializados e avaliação da qualidade microbiológica do produto. Hig. Aliment., 19(129), $32-$ 34.

25. Rodríguez, W.; Núñez, F.; Córdoba, J.J.; Bermúdez, E.; Asensio, M.A. (1996). Gram-positive, catalase-positive cocci from dry cured Iberian ham and their enterotoxigenic potential. Appl. Environ. Microbiol. 626, 1897-1902.

26. Simonovà, M.; Strompfovà, V.; Marcinàkovà, M.; Laukovà, A.; Vesterlund, S.; Moratalla, M.L.; Bover-Cid, S.; Vidal-Carou, C. (2006). Characterization of Staphylococcus xylosus and Staphylococcus carnosus isolated from Slovak meat products. Meat Sci., 73, 559564.

27. Valle, J.; Gomez-Lucia, E.; Piriz, S.; Goyache, J.; Orden, J.A.; Vadillo, S. (1990). Enterotoxin production by staphylococci isolated from goats. Appl. Enviro. Microbiol., 56, 1323-1326. 